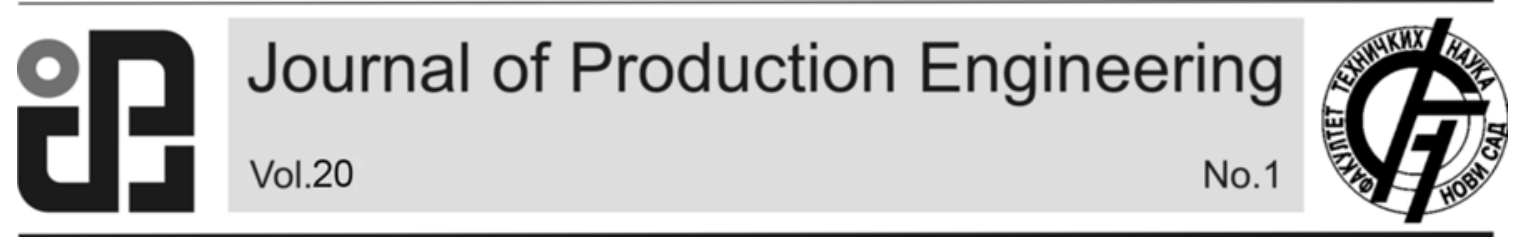

JPE (2017) Vol.20 (1)

Original Scientific Paper

Vrabel', M., Viňáš, J., Maňková, I., Brezinová, J., Savkovič, B., Kovač, P.

\title{
ANALYSIS OF TOOL WEAR PATTERNS IN ROUGH TURNING OF CHROMIUM HARDFACING MATERIAL
}

Received: 02 April 2017 / Accepted: 10 May 2017

\begin{abstract}
Weld cladding represents one of the major remanufacturing technology employed in renovation of the worn machine tool components used in steel industry. Welded layer deposited on roller, originating from hot rolling mill improve its properties such as wear resistance, corrosion resistance and oxidation resistance in elevated temperatures. Machining processes must by applied on the part after the process of deposition to achieve desired dimensional accuracy and required surface integrity of the final parts. Dynamic mechanical loads acting on a cutting tool due to variable chip cross-section, nature of carbides, their size and distribution makes rough machining of martensitic materials difficult to cut, especially with the respect to rapid tool wear. This paper discusses and summarizes various cutting tool wear patterns occurring in turning of high content chromium hardfacing layers. The results show that tool edge and tip breakage, as well as flank wear are typicall features of failured carbide tool under the consideration.
\end{abstract}

Key words: rough turning, martensitic alloy, hardfacing, tool wear, remanufacturing.

Analiza tragova habanja alata pri grubom struganju navarenog materijala hroma. Navarivanje predstavlja jedanu od glavnih tehnologija reproizvodnje primenjenih u renoviranje potrošenih komponenti alatnih mašina koje se koriste u metaloprerađivačkoj industriji. Zavareni sloj deponovan na valjak, poreklom iz vruće valjaonice poboljšava osobine kao što su otpornost na habanje, otpornost na koroziju i otpornost na oksidaciju na povišenim temperaturama. Procesi obrade moraju da se primene na delu nakon procesa deponovanja $i$ postizanja željene dimenzionalne preciznosti i potrebnog integriteta površine finalnih delova. Dinamičko mehanička opterećenja deluju na rezni alat zbog promenljivog poprečnog preseka strugotine, prirode karbida, njihove veličine $i$ distribucije koja čini mašinsku obradu martenzitnog materijala teškog za obradu, posebno se javlja pojava brzog habanja alata. Ovaj rad razmatra i rezimira različite pojave habanja alata pri struganju koji se javljaju kod slojeva hroma posle navarivanje sloja. Rezultati pokazuju da se ivica alata $i$ vrh krza, kao i da je pojas habanja tipične karakteristike za otkaza alata kod obrade tvrdog metala.

Ključne reči: grubo struganje, martenzitna legura, navarivanje, habanje alata, reproizvodnja.

\section{INTRODUCTION}

The challenge for modern machining industries is to achievement of product quality in terms of superior surface integrity, high dimensional accuracy, less tool wear, reduced manufacturing cost, and lessened environmental impact [1]. Remanufacturing technology has been used in practice for production of new parts with overlays, which have specific properties, and for renovation of the abraded, fatigued and fractured surfaces. In some cases, the use of suitable overlay can save materials and energy, optimize the part's performance, and expand the service life [2]. High chromium hardfacing materials are widely used in industry due to its excellent wear resistance. The wear resistance of these materials is mainly achieved by a high hardness and high carbide contents and this makes machining of these hardfacings extremely difficult [3]. Hardfacing materials are often applied to a substrate by welding to provide wear-resistant layers several millimetres thick. Subsequent machining is usually necessary to achieve required standards of dimensional accuracy and surface finish [4]. During turning one of the important factors is tool wear whether it is soft or hard machining. Flank wear is the most important wear which will affect the smoothness of the product, cost of operation and performance [5]. Tool wear mechanisms are generally influenced by four phenomenons namely: abrasion, thermal softening, diffusion and notching at depth of cut and trailing edge [6]. Jawaid et al. [7] in their research concluded, that significant nose wear was the common failure mode observed at higher speed conditions in machining of martensitic stainless steel with coated carbides. Moreover, plastic deformation and chipping/fracture at the cutting edge were additional failure modes observed within experimental trials. In this work, tool wear patterns and wear mechanisms when machining high chromium hardfacing material with TiAlN coated carbide tools were investigated and discussed.

\section{EXPERIMENTAL SETUP}

The aim of the experimental testing within this study was to analyze and document cutting tool wear occurring in machining of martensitic hardfacing material. Worn continuous caster roll originating from hot rolling mill was used as a workpiece material, whose nominal diameter was about $150 \pm 0,1 \mathrm{~mm}$ and total length was $1100 \mathrm{~mm}$. The initial diameter was 
increased to the value of approximately $160 \mathrm{~mm}$ by cladding process in which hardfacing overlay is applied on worn cylinder surface, see Fig. 1. Therefore, thickness of the overlay was about $5 \mathrm{~mm}$.

Renovation process of the roll was as follows:

- turning (removing the worn surface layer),

- cladding process

- post weld heat treatment,

- turning (roughing),

- turning (finishing).

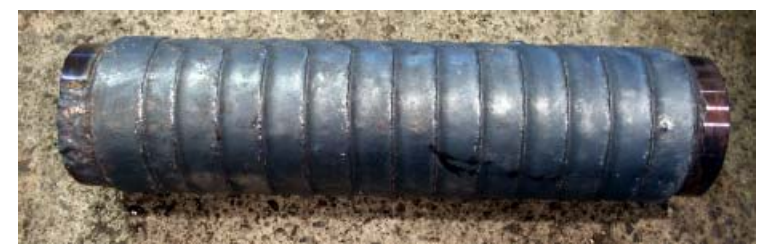

Fig. 1. Workpiece - roller after cladding process

Martensitic filler material Weldclad 3 (WLDC 3) with diameter of $2.4 \mathrm{~mm}$ from Corewire manufacturer was used in cladding process, see Tab. 1. This type of material is recommended by manufacturer for surfacing of continuous caster rolls by process of submerged-arc welding (SAW) with oscillating movement of the electrode tip. Recommended welding parameters are listed in Tab. 2. Cladding operation was performed using equipment from Lincoln Electric company. The welding process is illustrated in the Fig. 3 and Fig. 4, respectively.

\begin{tabular}{|c|c|c|c|c|c|c|c|}
\hline $\mathbf{C}$ & $\mathbf{M n}$ & $\mathbf{S i}$ & $\mathbf{C r}$ & $\mathbf{N i}$ & $\mathbf{M o}$ & $\mathbf{N b}$ & $\mathbf{V}$ \\
\hline 0.1 & 1 & 0.6 & 12.2 & 2.5 & 0.8 & 0.15 & 0.15 \\
\hline
\end{tabular}

Table 1. Nominal All Weld Composition, wt $\%$ (WLDC3) [8]

\begin{tabular}{|c|c|c|c|}
\hline $\begin{array}{c}\text { Pre heat } \\
{[\mathbf{C}]}\end{array}$ & $\begin{array}{c}\text { Wire Feed } \\
\text { Speed } \\
{[\text { in/min] }}\end{array}$ & $\begin{array}{c}\text { Amps } \\
{[\mathbf{A}]}\end{array}$ & $\begin{array}{c}\text { Volts } \\
{[\mathbf{V}]}\end{array}$ \\
\hline 250 & 2,97 & 400 & 29 \\
\hline $\begin{array}{c}\text { Travel } \\
\text { speed } \\
{[\mathbf{m m} / \mathbf{m i n}]}\end{array}$ & $\begin{array}{c}\text { Stick out } \\
{[\mathbf{m m}]}\end{array}$ & $\begin{array}{c}\text { Bead } \\
\text { Width } \\
{[\mathbf{m m}]}\end{array}$ & $\begin{array}{c}\text { Overlap } \\
{[\mathbf{m m}]}\end{array}$ \\
\hline 150 & 35 & 40 & 10 \\
\hline
\end{tabular}

Table 2. Welding parameters [8]

Post weld heat treatment (warming up to $520{ }^{\circ} \mathrm{C}$ for 4 hours and holding time for 8 hours) was applied to soften hardened metal. According to annealing curve of the filler material in Fig. 2, it is possible to determine the weld hardness, which in this case was in the range 44 to 50 HRc.

The TOS SUI 63-80 universal lathe was used to machine the roll after welding. Important parameters of the employed machine tool are summarized in Tab. 3 . The Korloy PSSNR3232-P19 cutting tool was used in rough turning operations and was clamped into Multifix tool holder, see Fig. 6. The whole experimental configuration is illustrated in Fig. 5. Main dimensions of the cutting insert CNMG160616 are shown in Fig. 7. Cutting material of the insert was TiAlN coated carbide (PC9030).

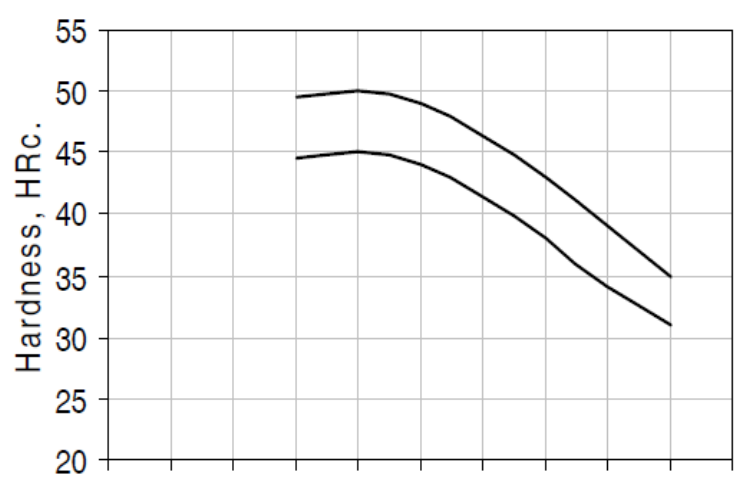

400425450475500525550575600625650

Tempering Temperature, ${ }^{\circ} \mathrm{C}$.

Fig. 2. Temper response [7]

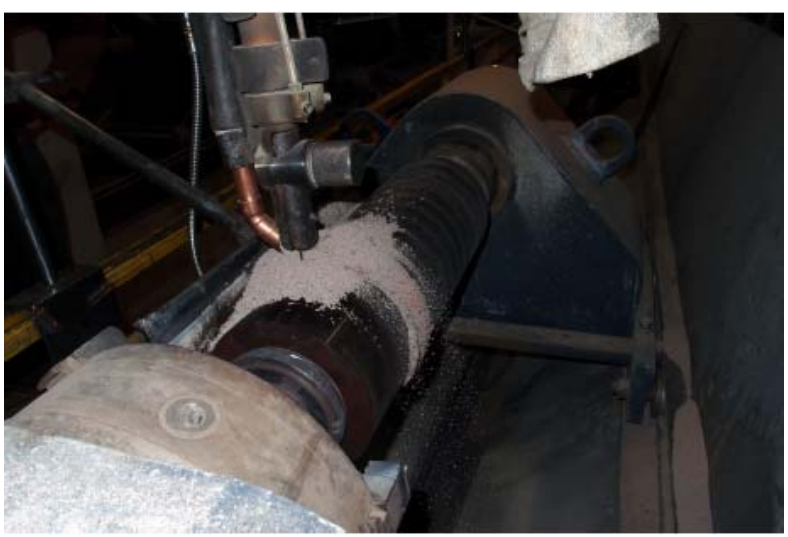

Fig. 3. Cladding layer formation process

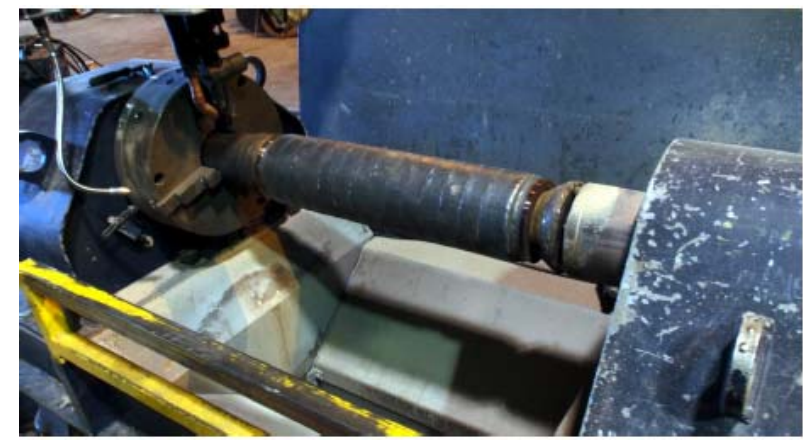

Fig. 4. Roller with hardfacing layer before machining process

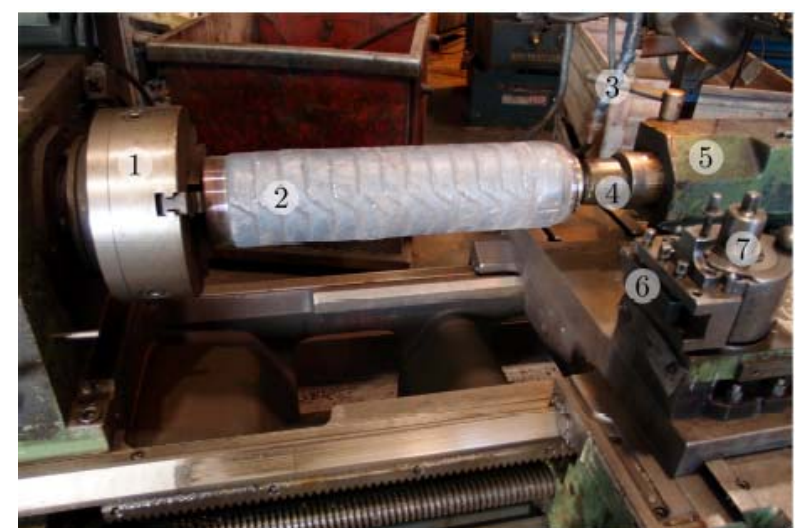

Fig. 5. Experimental configuration ( $1-3$ jaws chuck, 2 - workpiece, 3 - coolant supply, 4 - tailstock quill, 5 - tailstock assembly, 6 - cutting tool, 7 tool post) 


\begin{tabular}{|c|c|c|c|}
\hline $\begin{array}{c}\text { Swing } \\
\text { diameter } \\
{[\mathrm{mm}]}\end{array}$ & $\begin{array}{c}\text { Turning } \\
\text { diameter } \\
{[\mathrm{mm}]}\end{array}$ & $\begin{array}{c}\text { Stroke } \\
\text { in Z axis } \\
{[\mathrm{mm}]}\end{array}$ & $\begin{array}{c}\text { Bar capacity } \\
{[\mathrm{mm}]}\end{array}$ \\
\hline 630 & 350 & 1500 & 71 \\
\hline Main & $\begin{array}{c}\text { Speed } \\
\text { range } \\
\text { max. } \\
\text { power } \\
{[\mathrm{kW}]}\end{array}$ & $\begin{array}{c}\text { Workpie } \\
\text { ceweight } \\
\text { max. } \\
{[\mathrm{rpm}]}\end{array}$ & $\begin{array}{c}\text { Max. dimensions } \\
\text { of the cutting } \\
\text { tool (holder cross } \\
\text { - section) }\end{array}$ \\
\hline 15 & 1800 & 1600 & $40 \times 32$ \\
\hline
\end{tabular}

Table 3. Selected parameters of the universal lathe TOS SUI 63 - 80
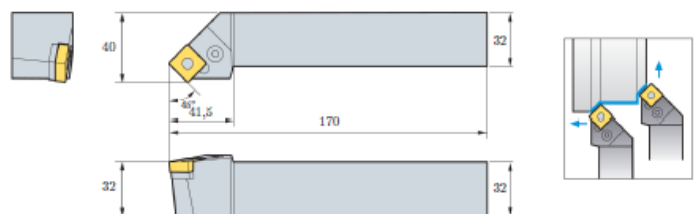

Fig. 6. Tool holder Korloy PSSNR3232-P19 [9]
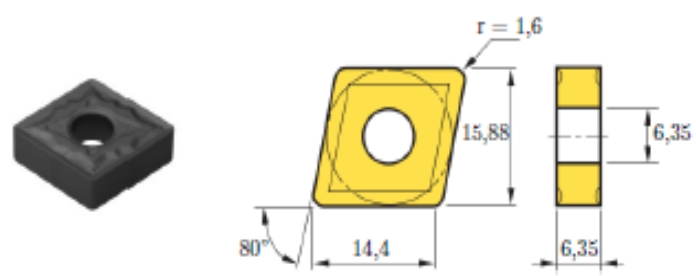

Fig. 7. Cutting insert Korloy CNMG160616-HS [9]

The welding parameters were used as those recommended by the manufacturers, except speed (160 $\left.\mathrm{mm} \cdot \mathrm{min}^{-1}\right)$, volts $(35 \mathrm{~V})$ and wire feed speed $(4,62$ $\left.\mathrm{m} \cdot \mathrm{min}^{-1}\right)$. The cutting conditions used for turning are compared with the recommended values by producer as listed in Tab. 4. An oil based cutting fluid of $8 \%$ concentration was used in machining tests.

\begin{tabular}{|c|c|c|}
\hline & Recommended & Used \\
\hline $\mathbf{a p}[\mathrm{mm}]$ & $2-6$ & 4 \\
\hline $\mathbf{f}[\mathrm{mm} / \mathrm{rev}]$ & $0.15-0.6$ & 0.33 \\
\hline $\mathbf{v}_{\mathbf{c}}[\mathrm{m} / \mathrm{min}]$ & $70-180$ & 40 \\
\hline
\end{tabular}

Table 4. Cutting conditions employed within experimental trials

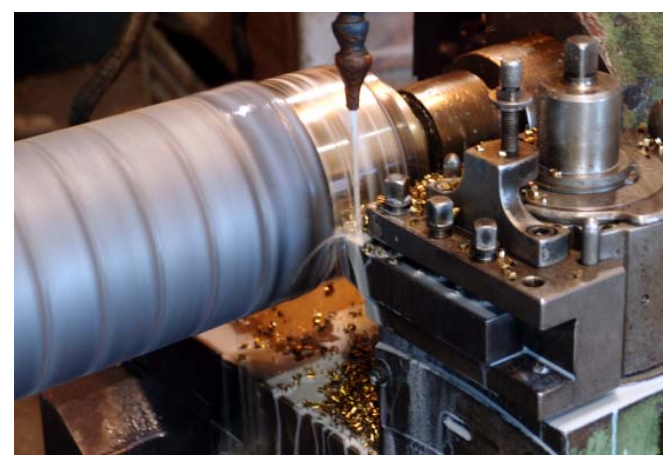

Fig. 8. Machining of the hardfacing layer

\begin{tabular}{|c|c|c|c|c|}
\hline $\begin{array}{c}\text { Side } \\
\text { rake } \\
\text { angle }\end{array}$ & $\begin{array}{c}\text { Clearanc } \\
\text { e angle }\end{array}$ & $\begin{array}{c}\text { Side } \\
\text { cutting } \\
\text { edge angle }\end{array}$ & $\begin{array}{c}\text { Back } \\
\text { rake } \\
\text { angle }\end{array}$ & $\begin{array}{c}\text { Nose } \\
\text { radiu } \\
\text { s }\end{array}$ \\
\hline$-8^{\circ}$ & $8^{\circ}$ & $45^{\circ}$ & $0^{\circ}$ & 1.6 \\
\hline
\end{tabular}

Table 5. Cutting tool geometry

\section{RESULTS AND DISCUSSION}

During the experiments, several types of cutting tool wear have been observed when machining chromium hardfacing overlay (Fig. $10-12$ ):

- flank wear,

- cutting edge chipping,

- notch wear,

- BUE formation,

- cutting edge and tool tip breakage/fracture.

As a predominant types of wear on the cutting wedge occurred:

- flak wear due to abrasive mechanism,

- main cutting edge an insert nose fracture

- built up edge formation

- notch wear corresponding to depth of cut.

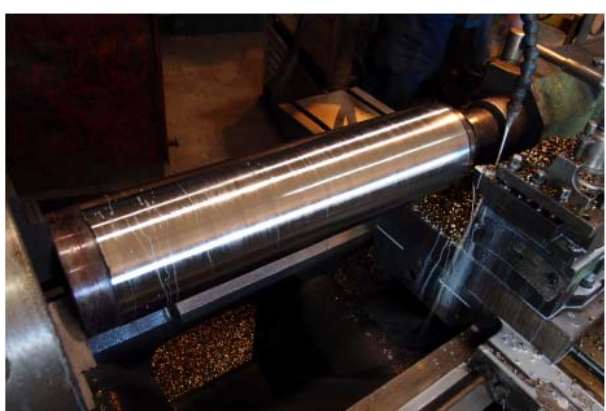

Fig. 9. Roller after roughing operation

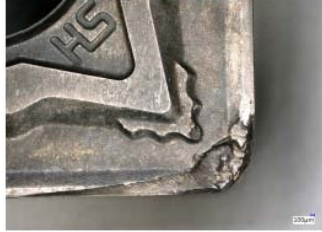

(a)

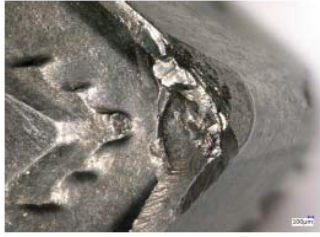

(c)

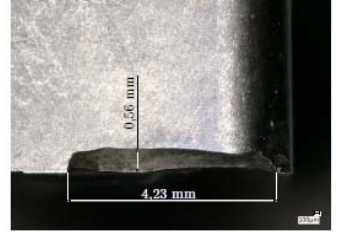

(b)

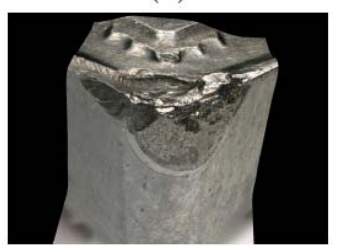

(d)
Fig. 10. Observed wear on the cutting insert No.1 (a, b - flank wear; c, d - nose chipping/breakage)

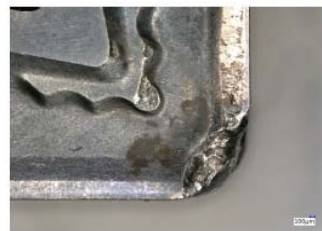

(a)

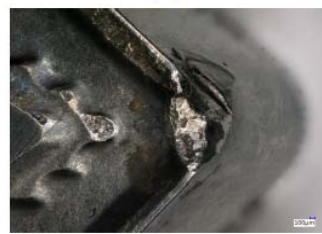

(c)

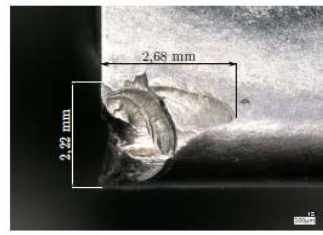

(b)

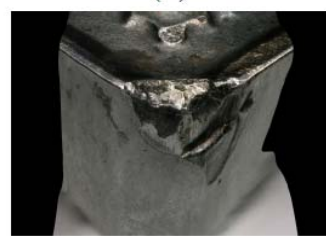

(d)
Fig. 11. Observed wear on the cutting insert No.2 (plastic deformation, built up edge - BUE, tip breakage) 


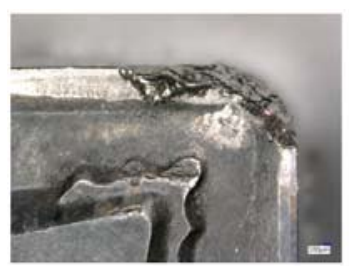

(a)

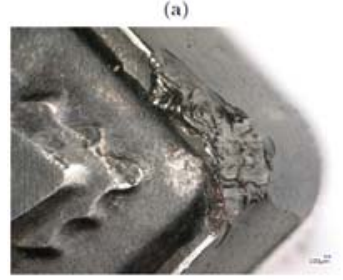

(c)

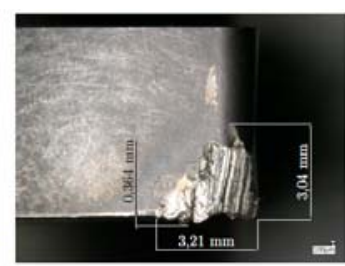

(b)

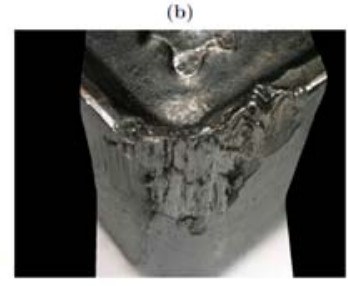

(d)
Fig. 12. Observed wear on the cutting insert No.2 (flank wear, built up edge)

\section{CONCLUSION}

Renovation of the continuous caster roll from hot mill used in steel industry was realised in this work. With regard to the welding and machining process parameters, tool wear of the coated carbide inserts in rough turning operation of the hardfacing layers (44 $50 \mathrm{HRc}$ ) with martensitic structure was evaluated. A common wear of the cutting edge was fracture/ breakage, which means sudden change in the geometry of the cutting wedge. This type of failure is particularly undesirable because it is not possible to reliably predict its occurrence, thus risk of the workpiece damage is significant. Insert brittle failure is caused in discontinuous cutting due to the varying depth of cut, which results to dynamic mechanical loads. In addition, this kind of wear may be the result of vibration as a consequence of insufficient rigidity of the machine tool, workpiece and fixture employed. Abrasion is also very common and often occurring wear mechanism when machining hard materials. During metal cutting of martensitic hardfacing overlays is abrasion and tool damage caused by hard carbide particles distributed in the workpiece material. Tool fatigue fracture occurs as a result of cylindrical workpiece run-out, which also markedly contributes to variable mechanical load and therefore results in unstable cutting.

\section{REFERENCES}

[1] Liu, Z. Q., Zhao, P. F.: An experimental and numerical analyses of hard turning AISI 440C Martensitic Steel, Materials Processing and Technoogy, Vol. 1, pp. 1-11, 2010.

[2] Wang, M., Xu, B., Zhang, J., Dong, S.: Experimental observations on surface roughness, chip morphology, and tool wear behavior in machining Fe-based amorphous alloy overlay for remanufacture, International Journal of Advanced Manufacturing Technology, Vol. 67, pp. 15371548, 2013.

[3] Ren, X. J., R., Yang, Q. X., James, R. D., Wang, L.: Cutting temperatures in hard turning chromium hardfacings with PCBN tooling, Journal of Material Processing Technology, Vol. 147, pp. 38-
44, 2004.

[4] Ren, X. J., James, R. D., Brookes, E. J., Wang, L.: Machining of high chromium hardfacing materials, Journal of Material Processing Technology, Vol. 115, pp. 423-429, 2001.

[5] Hasan, S., Thamizhmanii, S.: Tool flank wear analysis of AISI 440C martensitic stainless steel by turning, International Journal of Material Forming, Vol. 3, pp. 427-430, 2010.

[6] Thamizhmanii, S., Hasan, S.: Effect of tool wear and forces by turning process on hard AISI $440 \mathrm{C}$ and SCM 440 materials, International Journal of Material Forming, Vol. 3, pp. 531-534, 2009.

[7] Jawaid, A., Olajire, K. A., Ezugwu, E. O.: Machining of martensitic stainless steel (JETHETE) with coated carbides, Journal of Engineering Manufacture, Vol. 1, pp. 769-779.

[8] WLDC 3 Material data sheet (2017). www.corewire.com

[9] KORLOY (2017). www.korloy.com

\section{ACKNOWLEDGEMENT}

This work was supported by the Slovak Research and Development Agency under the contract of bilateral project APVV SK-SRB-2016-0045 and research project APVV-16-0359 as well as the project VEGA 1/0434/15. Moreover, authors wish to thank Faculty of Mechanical Engineering of TU in Košice for the material and financial support within the project "Development of the intelligent monitoring system for zero defect production". We are also grateful to Ing. Juraj Ondaš from Corwire Surface Technology s.r.o who provided expertise that greatly assisted the research.

Authors: Dr. Marek Vrabel', Assist. Prof. Dr. Ján Viňáš., Prof. Dr. Ildikó Maňková., Prof. Dr. Janette Brezinová., Technical University of Košice, Faculty of Mechanical Engineering, Deptartment of Manufacturing Technology and Materials, Mäsiarska 74, 04001 Košice, Assist. Prof. Dr. Borislav Savkovič., Prof. Dr. Pavel Kovač., University of Novi Sad, Faculty of Technical Sciences, Institute for Production Engineering, Trg Dositeja Obradovica 6, 21000 Novi Sad, Serbia, Phone.: +381 21 450-366, Fax: +381 21 454-495.

E-mail: marek.vrabel@tuke.sk jan.vinas@tuke.sk ildiko.mankova@tuke.sk janette.brezinova@tuke.sk savkovic@uns.ac.rs pkovac@uns.ac.rs 